Article

\title{
Growth Performance of Broilers as Influenced by Different Levels and Sources of Methionine Plus Cysteine
}

\author{
Abd Ur Rehman ${ }^{1}$, Muhammad Arif ${ }^{1}$, Muhammad M. Husnain ${ }^{1}$, Mahmoud Alagawany ${ }^{2}{ }^{(1)}$, \\ Mohamed E. Abd El-Hack ${ }^{2} *(\mathbb{D})$, Ayman E. Taha ${ }^{3}$ (D), Shaaban S. Elnesr ${ }^{4}$, Mervat A. Abdel-Latif ${ }^{5}$, \\ Sarah I. Othman ${ }^{6}$ and Ahmed A. Allam ${ }^{7}$ \\ 1 Department of Animal Sciences, College of Agriculture, University of Sargodha, Sargodha 40100, Pakistan; \\ thenutritionist@ymail.com (A.U.R.); arif.inayat@uos.edu.pk (M.A.); globalpeace84@gmail.com (M.M.H.) \\ 2 Department of Poultry, Faculty of Agriculture, Zagazig University, Zagazig 44511, Egypt; \\ dr.mahmoud.alagwany@gmail.com \\ 3 Department of Animal Husbandry and Animal Wealth Development, Faculty of Veterinary Medicine, \\ Alexandria University, Behira, Rasheed, Edfina 22758, Egypt; ayman.taha@alexu.edu.eg \\ 4 Department of Poultry Production, Faculty of Agriculture, Fayoum University, Fayoum 63514, Egypt; \\ ss00@fayoum.edu.eg \\ 5 Department of Nutrition and Veterinary Clinical Nutrition, Faculty of Veterinary Medicine, \\ Damanhour University, Damanhour 22511, Egypt; mervat.abdellatif@vetmed.dmu.edu.eg \\ 6 Biology Department, College of Science, Princess Nourah Bint Abdulrahman University, Riyadh 11671, \\ BO. Box 24428, Saudi Arabia; sialothman@pnu.edu.sa \\ 7 Department of Zoology, Faculty of Science, Beni-suef University, Beni-suef 65211, Egypt; \\ allam1081981@yahoo.com \\ * Correspondence: dr.mohamed.e.abdalhaq@gmail.com or m.ezzat@zu.edu.rg
}

Received: 3 November 2019; Accepted: 27 November 2019; Published: 1 December 2019

check for updates

Simple Summary: The current work evaluated the utilization of different sources of methionine either from DL-methionine (DL-Met) or L-methionine (L-Met) using different concentrations of dietary methionine plus cystine (Met + Cyst) in broiler chickens. Results showed that a better edible meat yield could be obtained by supplementing Met + Cyst at the rate of $80 \%$ of the digestible lysine.

\begin{abstract}
The objective of this work was to evaluate the utilization of methionine from DL-methionine (DL-Met) and L-methionine (L-Met) with different levels of dietary methionine plus cystine (Met + Cyst) in broilers. The experimental diets were formulated by using three levels of Met + Cyst, i.e., $74 \%$, $77 \%$ and $80 \%$ of digestible lysine. Met + Cyst was provided either from DL-Met or L-Met. A total of 450 day-old broilers were divided into six groups (five replicates of 15 birds each) in a $3 \times 2$ factorial arrangement under completely randomized design. Weight gain (WG), feed intake (FI) and feed conversion ratio (FCR) was determined. At the end of the experiment (35 days), two birds from each replicate were slaughtered to determine carcass characteristics and serum homocysteine. Results indicate that the combined effect of L-Met and DL-Met significantly affected $(p<0.05)$ the WG in the starter period and FI in the finisher period. Neither source nor level of methionine influenced $(p>0.05)$ the FI, WG and FCR of broilers during the starter, finisher or overall phase of growth. The interaction between sources and levels of methionine did not influence $(p>0.05)$ the feed intake, weight gain and FCR during the overall phase of growth. Source of methionine had no $(p>0.05)$ effect on carcass characteristics. Methionine levels had a significant effect $(p<0.05)$ on carcass weight, chest weight and thigh weight. The interaction between sources and levels of methionine had a significant $(p<0.05)$ effect on the liver weight. The sources of methionine had significant $(p<0.05)$ effects on the liver and heart weight, while methionine levels significantly influenced $(p<0.05)$ the liver and gizzard weight. Finally, it was concluded that if DL-Met and L-Met are included in feed at a standard level, they are equally effective as a source of methionine for broilers.
\end{abstract}


Keywords: methionine; levels; sources; growth; carcass; broiler

\section{Introduction}

Methionine has a vital role in the metabolic functioning of animals and humans, which is why it is also known as functional amino acid. Methionine is considered as the first limiting amino acid in broilers and its deficiency may cause reduced growth performance, metabolic disorder and impaired immune system [1,2]. It plays a vital role in the production of energy through the synthesis of protein; it also enhances the broilers' livability, efficiency of feed and growth performance [3-5]. Also, a methyl group that is provided by sulfur-adenosyl methionine is required for many metabolic reactions such as epinephrine, carnitine, choline and creatine synthesis $[5,6]$. Synthetic sources of methionine (L-methionine (L-Met), DL-methionine (DL-Met) and DL-2 hydroxy-4-(methyl) butanoic acid (LMA)) are included in commercial broiler feed to optimize the dietary level of methionine. However, synthetic methionine is very expensive and the availability of methionine from different synthetic sources is controversial [7]. The availability of methionine from L-Met, DL-Met and LMA is $100 \%, 99 \%$ and $88 \%$, respectively. L-Met is directly used by the animal as a precursor for protein synthesis and metabolized through the trans-sulfuration pathway to produce cysteine and glutathione [8,9]. Methionine hydroxy analog free acid (MHA-FA) is chemically different from DL-Met because it has a hydroxyl group at the asymmetric carbon atom, whereas DL-Met has an amino group. This chemical difference lowers the bio-availability of MHA compared to DL-Met $[10,11]$.

Different levels of methionine in the diet of poultry have been reported by researchers, ranging from $0.3-1.2 \%$ during the initial period and $0.3-0.9 \%$ during the growth period of poultry. It has been suggested that commercial poultry production does not need more than $0.38 \%$ and $0.50 \%$ methionine in grower and starter diets, respectively, for the optimum feed efficiency and growth of broilers, although high rates of methionine are necessary to boost the immune system [12]. Reports regarding the dietary level of methionine are controversial. Kalinowski [13] studied the effect of DL-Met levels $(0.32 \%, 0.38 \%$, $0.44 \%$, and $0.50 \%$ ) with a constant level of L-cystine $(0.40 \%)$ on slow and fast growing broilers from 3 to 6 weeks of age, and observed that weight gain was not affected and the feed conversion ratio (FCR) was improved with the highest level of methionine. However, Xie et al. [14] reported that increasing levels of DL-methionine $(0.285 \%, 0.385 \%, 0.485 \%, 0.585 \%$ or $0.685 \%)$ resulted in decreased feed intake and weight gain because of higher plasma homocysteine concentration. This might be related to differences in the source of methionine used. Because of deamination of other amino acids during conversion of D-Met to L-Met, different sources of methionine may perform differently. Ribeiro et al. [8] observed that L-Met addition in broiler diet provided better FCR as compared to DL-Met, and MHA. Lui et al. [15] observed that the bioavailability of MHA-FA was greater than DL-Met. Data regarding the use of different methionine sources with varying dietary Met + Cyst levels are scarce, thus the main objective of this study was to evaluate the utilization of methionine from DL-Met and L-Met with different levels of dietary Met + Cyst in broilers.

\section{Materials and Methods}

The animal experiment was conducted in accordance with the recommendations and guidelines of the Committee on the Ethics of Animal Experiments of Sargodha University, Sargodha, Pakistan. 


\subsection{Experimental Design, Birds and Diets}

The experiment was conducted at the poultry research center at the College of Agriculture, University of Sargodha (Sargodha, Pakistan). A total of 450 day-old broiler chickens (Ross 308-mixed sex) with similar body weight were randomly divided into 6 groups in a $3 \times 2$ factorial arrangement under completely randomized design (CRD). Each group had five replicates (pens) of 15 birds. Six experimental diets were formulated (Tables 1 and 2 ) by using 3 levels of Met + Cyst (74\%, 77\% and $80 \%$ of digestible lysine) and two sources (DL-Met and L-Met) of methionine. Chickens were reared in suitable pens, under the same managerial, hygienic and environmental conditions. Each diet was randomly allotted to each group for five consecutive successive weeks.

Table 1. Ingredients and nutrients of starter diets (1-21 days).

\begin{tabular}{|c|c|c|c|c|c|c|}
\hline \multirow{2}{*}{ Ingredients (\%) } & \multicolumn{6}{|c|}{${ }^{1}$ Diets } \\
\hline & DLM74 & DLM77 & DLM80 & LM74 & LM77 & LM80 \\
\hline Maize & 18.85 & 18.85 & 18.85 & 18.85 & 18.85 & 18.85 \\
\hline Rice Tips & 28 & 28 & 28 & 28 & 28 & 28 \\
\hline Soybean Meal & 26.23 & 26.23 & 26.23 & 26.23 & 26.23 & 26.23 \\
\hline Canola & 16 & 16 & 16 & 16 & 16 & 16 \\
\hline Rice Polish & 4.9 & 4.9 & 4.9 & 4.9 & 4.9 & 4.9 \\
\hline Vegetable Oil & 2.85 & 2.85 & 2.85 & 2.85 & 2.83 & 2.8 \\
\hline Limestone & 1.01 & 1.01 & 1.01 & 1.01 & 1.01 & 1.01 \\
\hline Di-calcium phosphate & 1 & 1 & 1 & 1 & 1 & 1 \\
\hline Salt & 0.3 & 0.3 & 0.3 & 0.3 & 0.3 & 0.3 \\
\hline Lysine & 0.408 & 0.408 & 0.408 & 0.408 & 0.408 & 0.408 \\
\hline DL-Methionine & 0.245 & 0.282 & 0.319 & 0 & 0 & 0 \\
\hline L-Methionine & 0 & 0 & 0 & 0.245 & 0.282 & 0.319 \\
\hline Premix * & 0.1 & 0.1 & 0.1 & 0.1 & 0.1 & 0.1 \\
\hline L-Threonine & 0.085 & 0.085 & 0.085 & 0.085 & 0.085 & 0.085 \\
\hline Extra XAP & 0.01 & 0.01 & 0.01 & 0.01 & 0.01 & 0.01 \\
\hline \multirow[t]{2}{*}{ Extra Phytase } & 0.01 & 0.01 & 0.01 & 0.01 & 0.01 & 0.01 \\
\hline & \multicolumn{6}{|c|}{ Nutrients $(\%)$} \\
\hline $\mathrm{ME}(\mathrm{Kcal} / \mathrm{Kg})$ & 2870 & 2870 & 2870 & 2870 & 2870 & 2870 \\
\hline Crude Protein & 22.1 & 22.1 & 22.1 & 22.1 & 22.1 & 22.1 \\
\hline Calcium & 1 & 1 & 1 & 1 & 1 & 1 \\
\hline Available P & 0.45 & 0.45 & 0.45 & 0.45 & 0.45 & 0.45 \\
\hline D-Lysine & 1.22 & 1.22 & 1.22 & 1.22 & 1.22 & 1.22 \\
\hline D-Methionine & 0.57 & 0.606 & 0.643 & 0.57 & 0.606 & 0.643 \\
\hline Methionine + Cysteine & 0.903 & 0.940 & 0.976 & 0.903 & 0.940 & 0.976 \\
\hline
\end{tabular}

${ }^{1}$ LM 74, 77 and 80 and DLM 74, 77 and 80 indicate inclusion of L-methionine and DL-methionine at the rate of $74 \%, 77 \%$ and $80 \%$ of digestible lysine, respectively. ME = Metabolizable energy. ${ }^{*}$ Provides per kg of diet: 20 MIU Vitamin A; 5 MIU Vitamin D3; 60 g Vitamin E 50; 2 g Vitamin K3; 6 g Vitamin B2; 45 g Vitamin B3; 12 g Vitamin B5; $5 \mathrm{~g}$ Vitamin B6; $12.5 \mathrm{~g}$ Vitamin B9; $12.5 \mathrm{~g}$ Vitamin B12; $275 \mathrm{~g}$ Manganese $\left(\mathrm{MnSO}_{4}\right) ; 150 \mathrm{~g}$ Ferrous $\left(\mathrm{FeSO}_{4}\right) ; 200 \mathrm{~g} \mathrm{Zn}$ $\left(\mathrm{ZnSO}_{4}\right) ; 75 \mathrm{~g} \mathrm{Cu}\left(\mathrm{CuSO}_{4}\right) ; 75 \mathrm{~g}$ Selenium; $4 \mathrm{~g}$ Potassium iodide.

\subsection{Housing and Management}

The housing area was cleaned and fumigated before the arrival of the chicks. Fumigation was done by using $\mathrm{KMnO}_{4}$ and formalin. Similar management conditions (floor space, temperature, relative humidity, light and ventilation) were provided to all replicates. Feed and water were provided ad libtium. 
Table 2. Ingredients and nutrients of finisher diets (22-35 days).

\begin{tabular}{|c|c|c|c|c|c|c|}
\hline \multirow{2}{*}{ Ingredients (\%) } & \multicolumn{6}{|c|}{${ }^{1}$ Diets } \\
\hline & DLM74 & DLM77 & DLM80 & LM74 & LM77 & LM80 \\
\hline Maize & 22.2 & 22.2 & 22.2 & 22.2 & 22.1 & 22 \\
\hline Rice Tips & 32 & 32 & 32 & 32 & 32 & 32 \\
\hline Soybean Meal & 24.33 & 24.33 & 24.33 & 24.33 & 24.33 & 24.33 \\
\hline Canola & 7.462 & 7.462 & 7.462 & 7.462 & 7.462 & 7.462 \\
\hline Rice Polish & 4.9 & 4.9 & 4.9 & 4.9 & 4.9 & 4.9 \\
\hline Vegetable Oil & 3.75 & 3.75 & 3.75 & 3.75 & 3.75 & 3.75 \\
\hline Limestone & 1.09 & 1.09 & 1.09 & 1.09 & 1.09 & 1.09 \\
\hline Di-calcium phosphate & 0.8 & 0.8 & 0.8 & 0.8 & 0.8 & 0.8 \\
\hline Salt & 0.3 & 0.3 & 0.3 & 0.3 & 0.3 & 0.3 \\
\hline Lysine & 0.458 & 0.458 & 0.458 & 0.458 & 0.458 & 0.458 \\
\hline DL-Methionine & 0.247 & 0.282 & 0.317 & 0 & 0 & 0 \\
\hline L-Methionine & 0 & 0 & 0 & 0.247 & 0.282 & 0.317 \\
\hline L-Threonine & 0.15 & 0.15 & 0.15 & 0.15 & 0.15 & 0.15 \\
\hline Premix * & 0.1 & 0.1 & 0.1 & 0.1 & 0.1 & 0.1 \\
\hline Extra XAP & 0.01 & 0.01 & 0.01 & 0.01 & 0.01 & 0.01 \\
\hline Extra Phytase & 0.01 & 0.01 & 0.01 & 0.01 & 0.01 & 0.01 \\
\hline \multicolumn{7}{|c|}{ Nutrients (\%) } \\
\hline $\mathrm{ME}(\mathrm{Kcal} / \mathrm{Kg})$ & 3040 & 3040 & 3040 & 3040 & 3040 & 3040 \\
\hline Crude Protein & 20 & 20 & 20 & 20 & 20 & 20 \\
\hline Calcium & 0.95 & 0.95 & 0.95 & 0.95 & 0.95 & 0.95 \\
\hline Available P & 0.44 & 0.44 & 0.44 & 0.44 & 0.44 & 0.44 \\
\hline D-Lysine & 1.1 & 1.1 & 1.1 & 1.1 & 1.1 & 1.1 \\
\hline D-Methionine & 0.529 & 0.563 & 0.597 & 0.529 & 0.563 & 0.597 \\
\hline Methionine + Cystine & 0.814 & 0.847 & 0.880 & 0.814 & 0.847 & 0.880 \\
\hline
\end{tabular}

\subsection{Growth Performance}

Feed intake and weight gain were recorded through the test periods (the starter period corresponds to 1-21 days of age, the finisher period to 22-35 days of age, and the overall period to 1-35 days of age). The feed intake was calculated by the difference between feed supplied and refusal at each period. The feed conversion ratio (FCR) was calculated by dividing feed intake by weight gain [16].

\subsection{Carcass Evaluation and Serum Homocysteine}

At the end of the experiment, two birds of average body weight from each replicate were randomly selected and slaughtered to determine the carcass characteristics (live weight, carcass weight, eviscerated weight, chest weight and thigh weight) and weight of visceral organs (liver, heart and gizzard).

\subsection{Blood Sampling}

Blood samples $(n=5)$ were collected from the wing vein at 35 days of age without anticoagulant for serum separation. Samples were centrifuged at $1435 \times \mathrm{g}$ for $5 \mathrm{~min}$ at $4{ }^{\circ} \mathrm{C}$ to obtain clear sera, which was collected for homocysteine analysis using chromatographic assay [17]. 


\subsection{Statistical Analysis}

Data collected were analyzed by using the analysis of variance technique in a $3 \times 2$ factorial arrangement under CRD. Means of all parameters were separated by using Tukey's test with the assistance of software (SAS ${ }^{\circledR} 9.3$ Software).

\section{Results}

\subsection{Growth Performance}

The combined effect of L-Met and DL-Met significantly affected $(p<0.05)$ the weight gain of broilers in the starter period. Neither the source nor levels of methionine influenced $(p>0.05)$ the feed intake, weight gain and FCR of broilers during the starter, finisher or the whole period (Table 3).

Table 3. Effect of different sources and levels of methionine plus cystine on growth performance of broilers during the starter and finisher phases.

\begin{tabular}{|c|c|c|c|c|c|c|}
\hline \multirow{2}{*}{$\begin{array}{c}\text { Treatments } \\
\text { Source } \times \text { Level }\end{array}$} & \multicolumn{2}{|c|}{ Feed Intake (g) } & \multicolumn{2}{|c|}{ Weight Gain (g) } & \multicolumn{2}{|c|}{ FCR (g Feed/g Gain) } \\
\hline & 1-21 days & 22-35 days & 1-21 days & 22-35 days & 1-21 days & 22-35 days \\
\hline LM 74 & 1321.5 & $2105.0^{b}$ & $934.8^{b}$ & 1282.4 & 1.4191 & 1.9386 \\
\hline LM 77 & 1342.8 & $2149.1^{a, b}$ & $1011.8^{a}$ & 1209.1 & 1.3291 & 1.7873 \\
\hline LM 80 & 1338.2 & $2154.9^{\mathrm{a}}$ & $1023.4^{\mathrm{a}}$ & 1282.5 & 1.3076 & 1.8108 \\
\hline DLM 74 & 1335.1 & $2077.3^{b}$ & $914.1^{\mathrm{b}}$ & 1129.0 & 1.3293 & 1.6395 \\
\hline DLM 77 & 1320.8 & $2097.3^{b}$ & $1005.7^{\mathrm{a}}$ & 1188.9 & 1.4054 & 1.8183 \\
\hline DLM 80 & 1331.5 & $2150.7^{\mathrm{a}}$ & $1008.1^{a}$ & 1214.9 & 1.3225 & 1.6195 \\
\hline \multirow[t]{2}{*}{ SEM } & 5.857 & 15.630 & 18.002 & 68.759 & 0.0262 & 0.0142 \\
\hline & & & Source & & & \\
\hline LM & 1334.2 & 2134.9 & 990.00 & 1258.0 & 1.3524 & 1.8455 \\
\hline DLM & 1329.1 & 2109.8 & 984.97 & 1177.6 & 1.3519 & 1.6925 \\
\hline \multirow[t]{2}{*}{ SEM } & 3.382 & 9.0243 & 10.393 & 39.698 & 0.0151 & 0.0601 \\
\hline & & & Level & & & \\
\hline 74 & 1328.3 & 2123.2 & 970.3 & 1205.7 & 1.3742 & 1.7891 \\
\hline 77 & 1331.8 & 2129.9 & 976.4 & 1199.0 & 1.3672 & 1.8028 \\
\hline 80 & 1334.8 & 2114.0 & 1015.8 & 1248.7 & 1.3150 & 1.7151 \\
\hline \multirow[t]{2}{*}{ SEM } & 4.142 & 11.052 & 12.72 & 48.620 & 0.0185 & 0.0737 \\
\hline & & & $p$-Values & & & \\
\hline Source $\times$ Level & NS & * & $*$ & NS & NS & NS \\
\hline Source & NS & NS & NS & NS & NS & NS \\
\hline Level & NS & NS & NS & NS & NS & NS \\
\hline
\end{tabular}

LM 74, 77 and 80 and DLM 74, 77 and 80 indicate inclusion of L-methionine and DL-methionine at the rate of 74\%, $77 \%$ and $80 \%$ of digestible lysine, respectively. ${ }^{\mathrm{a}, \mathrm{b}}$ Means sharing different superscripts differ significantly $(p<0.05)$. NS $=$ Non-significant $(p>0.05) \cdot{ }^{*}=$ Significant $(p<0.05)$.

Data presented in Table 3 indicate that the interaction between source and levels of methionine had a significant effect $(p<0.05)$ on the feed intake and weight gain during the finisher and starter period, respectively. The results regarding feed intake in the finisher period revealed that the best values $(p<0.05)$ were achieved at an $80 \%$ ratio of L-Met. However, no significant differences in feed intake were observed between LM80 and DLM80. During the starter period, the highest values of weight gain $(p<0.05)$ were achieved with a $77 \%$ or $80 \%$ ratio of L-Met and DLM in comparison with a ratio of $74 \%$.

As shown in Table 4, the interaction between sources and levels of methionine did not influence $(p>0.05)$ the feed intake, weight gain and FCR during the overall phase of growth. 
Table 4. Effect of different sources and levels of methionine plus cystine on growth performance of broilers during overall experimental period (1-35 days).

\begin{tabular}{|c|c|c|c|}
\hline Treatments & Feed Intake (g) & Weight Gain (g) & FCR (g Feed/g Gain) \\
\hline \multicolumn{4}{|c|}{ Source $\times$ Level } \\
\hline LM 74 & 3470.5 & 2288.1 & 1.6931 \\
\hline LM 77 & 3447.8 & 2150.2 & 1.5739 \\
\hline LM 80 & 3488.9 & 2290.6 & 1.5692 \\
\hline DLM 74 & 3432.5 & 2063.8 & 1.5015 \\
\hline DLM 77 & 3475.6 & 2200.7 & 1.6284 \\
\hline DLM 80 & 3408.8 & 2238.3 & 1.4891 \\
\hline SEM & 18.641 & 78.525 & 0.0570 \\
\hline \multicolumn{4}{|c|}{ Source } \\
\hline LM & 3469.1 & 2243.0 & 1.6120 \\
\hline DLM & 3439.0 & 2167.6 & 1.5397 \\
\hline SEM & 10.762 & 45.337 & 0.0329 \\
\hline \multicolumn{4}{|c|}{ Level } \\
\hline 74 & 3451.5 & 2176.0 & 1.5973 \\
\hline 77 & 3461.7 & 2175.5 & 1.6011 \\
\hline 80 & 3448.8 & 2264.5 & 1.5292 \\
\hline SEM & 13.181 & 55.526 & 0.0403 \\
\hline \multicolumn{4}{|c|}{$p$-Values } \\
\hline Source $\times$ Level & NS & NS & NS \\
\hline Source & NS & NS & NS \\
\hline Level & NS & NS & NS \\
\hline
\end{tabular}

LM 74, 77 and 80 and DLM 74, 77 and 80 indicate inclusion of L-methionine and DL-methionine at the rate of $74 \%$, $77 \%$ and $80 \%$ of digestible lysine, respectively. NS = Non-significant $(p>0.05)$.

\subsection{Carcass Characteristics}

The source $\times$ level of methionine had a significant $(p<0.05)$ effect on thigh weight and nonsignificant $(p>0.05)$ effect on live weight, carcass weight, after skin removal, eviscerated weight and chest weight (Table 5). The source of methionine had a non-significant effect $(p>0.05)$ on the carcass characteristics of broilers. Level of methionine had a significant $(p<0.05)$ effect on carcass weight, chest weight and thigh weight and a non-significant $(p>0.05)$ effect on live weight, after skin removal and eviscerated weight.

\subsection{Weight of the Visceral Organs}

As presented in Table 6, the interaction between sources and levels of methionine had a significant $(p<0.05)$ effect on liver weight, while the effect on heart and gizzard weight was non-significant $(p>0.05)$. On the other hand, with regard to liver weight, there was no significant difference between LM80 and DLM80. The sources of methionine had a significant $(p<0.05)$ effect on the liver and heart weight while the effect on the gizzard weight was non-significant $(p>0.05)$, since LM increases liver and heart weight when compared to DLM. Liver and gizzard weights were gradually increased as the levels of methionine increased from $74 \%$ to $77 \%$ to $80 \%(p<0.05)$. 
Table 5. Effect of different sources and levels of methionine plus cystine on carcass characteristics of broilers.

\begin{tabular}{|c|c|c|c|c|c|c|}
\hline Treatments & $\begin{array}{l}\text { Live Weight } \\
\text { (g) }\end{array}$ & $\begin{array}{l}\text { Carcass } \\
\text { Weight (g) }\end{array}$ & $\begin{array}{c}\text { After Skin } \\
\text { Removal (g) }\end{array}$ & $\begin{array}{l}\text { Eviscerated } \\
\text { Weight (g) }\end{array}$ & $\begin{array}{l}\text { Chest } \\
\text { Weight (g) }\end{array}$ & $\begin{array}{c}\text { Thigh } \\
\text { Weight (g) }\end{array}$ \\
\hline \multicolumn{7}{|c|}{ Source $\times$ Level } \\
\hline LM 74 & 2051.2 & 1979.4 & 1721.0 & 1329.2 & 581.60 & $528.20^{b}$ \\
\hline LM 77 & 2096.0 & 2027.2 & 1801.0 & 1560.2 & 642.00 & $548.00^{a, b}$ \\
\hline LM 80 & 2368.4 & 2288.8 & 2002.8 & 1747.4 & 685.00 & $620.60^{a}$ \\
\hline DLM 74 & 2067.2 & 1992.8 & 1729.0 & 1804.0 & 584.60 & $489.90^{\mathrm{b}}$ \\
\hline DLM 77 & 2157.4 & 2087.6 & 1830.4 & 1491.0 & 614.60 & $531.00^{a, b}$ \\
\hline DLM 80 & 2180.0 & 2118.6 & 1792.0 & 1538.0 & 643.00 & $573.80^{\mathrm{a}}$ \\
\hline SEM & 93.01 & 85.12 & 82.45 & 166.58 & 27.27 & 26.68 \\
\hline \multicolumn{7}{|c|}{ Source } \\
\hline LM & 2171.9 & 2098.5 & 1841.5 & 1545.6 & 636.20 & 552.83 \\
\hline DLM & 2134.9 & 2066.3 & 1783.8 & 1611.0 & 614.0 & 544.33 \\
\hline SEM & 53.70 & 49.14 & 47.60 & 96.17 & 15.74 & 15.40 \\
\hline \multicolumn{7}{|c|}{ Level } \\
\hline 74 & 2059.2 & $1981.1^{b}$ & 1725.0 & 1566.6 & $583.10^{\mathrm{b}}$ & $509.05^{b}$ \\
\hline 77 & 2126.7 & $2057.4^{\mathrm{a}, \mathrm{b}}$ & 1815.7 & 1525.6 & $628.30^{a, b}$ & $539.50^{a, b}$ \\
\hline 80 & 2274.2 & $2203.7^{a}$ & 1897.3 & 1642.7 & $664.00^{\mathrm{a}}$ & $597.20^{a}$ \\
\hline SEM & 65.77 & 60.19 & 58.30 & 117.8 & 19.28 & 18.87 \\
\hline \multicolumn{7}{|c|}{$p$-Value } \\
\hline Source $\times$ Level & NS & NS & NS & NS & NS & $*$ \\
\hline Source & NS & NS & NS & NS & NS & NS \\
\hline Level & NS & $*$ & NS & NS & $*$ & $*$ \\
\hline
\end{tabular}

Table 6. Effect of different sources and levels of methionine plus cystine on visceral organs and serum homocysteine of broilers.

\begin{tabular}{|c|c|c|c|c|}
\hline Treatments & Liver (g) & Heart (g) & Gizzard (g) & Serum Homocysteine $\mu \mathrm{mol} / \mathrm{L}$ \\
\hline \multicolumn{5}{|c|}{ Source $\times$ Level } \\
\hline LM 74 & $51.0^{\mathrm{b}}$ & 21.4 & 65.4 & 47.40 \\
\hline LM 77 & $54.1^{\mathrm{a}, \mathrm{b}}$ & 21.0 & 73.0 & 54.62 \\
\hline LM 80 & $60.6^{\mathrm{a}}$ & 17.2 & 78.8 & 58.74 \\
\hline DLM 74 & $43.4^{\mathrm{b}}$ & 13.8 & 69.1 & 52.46 \\
\hline DLM 77 & $52.4^{\mathrm{a}, \mathrm{b}}$ & 14.0 & 76.0 & 44.76 \\
\hline DLM 80 & $54.0^{\mathrm{a}}$ & 12.6 & 74.4 & 52.48 \\
\hline SEM & 2.78 & 1.98 & 3.67 & 4.686 \\
\hline \multicolumn{5}{|c|}{ Source } \\
\hline LM & $55.523^{\mathrm{a}}$ & $19.867^{\mathrm{a}}$ & 72.400 & 59.900 \\
\hline DLM & $49.933^{b}$ & $13.467^{b}$ & 73.167 & 53.687 \\
\hline SEM & 1.6059 & 1.1470 & 2.1236 & 2.706 \\
\hline \multicolumn{5}{|c|}{ Level } \\
\hline 74 & $48.75^{b}$ & 17.6 & $67.25^{b}$ & 50.080 \\
\hline 77 & $52.50^{\mathrm{a}, \mathrm{b}}$ & 17.5 & $74.50^{\mathrm{a}, \mathrm{b}}$ & 49.690 \\
\hline 80 & $56.50^{\mathrm{a}}$ & 14.9 & $76.60^{\mathrm{a}}$ & 55.610 \\
\hline SEM & 1.966 & 1.404 & 2.600 & 3.3141 \\
\hline \multicolumn{5}{|l|}{$p$-Value } \\
\hline Source $\times$ Level & * & NS & NS & NS \\
\hline Source & * & $*$ & NS & NS \\
\hline Level & * & NS & $*$ & NS \\
\hline
\end{tabular}

LM 74, 77 and 80 and DLM 74, 77 and 80 indicate inclusion of L-methionine and DL-methionine at the rate of 74\%, $77 \%$ and $80 \%$ of digestible lysine, respectively. $\mathrm{a}, \mathrm{b}$ Means sharing different superscripts differ significantly $(p<0.05)$. NS $=$ Non-significant $(p>0.05) .{ }^{*}=$ Significant $(p<0.05)$. 


\subsection{Serum Homocysteine}

The combined effect of L-Met and DL-Met had no $(p>0.05)$ effect on serum homocysteine level (Table 6). Neither source nor level of methionine had a significant $(p>0.05)$ influence on serum homocysteine level.

\section{Discussion}

The body weight gain of broilers was significantly increased $(p<0.05)$ in the starter period due to the combined effect of L-Met and DL-Met. These findings of growth performance confirmed the reports of earlier researchers, Ahmed and Abbas [18] who studied the effect of dietary methionine levels above the nutrient requirements of poultry (NRC) [19] recommendation on performance and carcass traits in broiler birds. Four dietary levels of methionine, $0 \%, 100 \%, 120 \%$ and $130 \%$ of the NRC recommendation were used. Weight gain was significantly higher by $110 \%$ and $130 \%$ of NRC methionine than that of the control diet. Better weight gain with L-Met than DL-Met is also supported by the findings of Katz and Baker [20] who observed that L-Met provided better and more efficient weight gain than D-Met or DL-Met. At a level of supplementation near the requirement, equal efficiency was attained because L-Met is $100 \%$ absorbed in the body as compared to DL-Met.

The feed intake and FCR in the starter period remained unchanged by the combined effect of L-Met and DL-Met; this is supported by other researchers [21,22] who have also observed no significant difference in feed intake and FCR due to supplementation of L-Met and DL-Met because when the diet was supplemented with methionine alone, some methionine was converted to cysteine. The presence of small excess amounts of cysteine depressed the feed intake without a proportional reduction in weight gain because the presence of cysteine reduces the metabolic damage. The combined expression of methionine and cystine as sulfur amino acids restricts the efficient use of feedstuff, and also results in inconsistency in requirements. The conversion of methionine to cysteine was nonequivalence [23] and cystine oxidation occurs when it increases beyond the limit, resulting in inefficiency in the accurate estimate of the requirement of individuals. The replacement value for cysteine in broilers that are 3-6 weeks old is 52\% [24], however, Wheeler and Latshaw [25] reported 43\% and NRC [18] reported $47 \%$ as the recommended value. It has been estimated that about $10 \%$ of dietary protein is diverted by the broiler in the first 6 weeks to the formation of feathers [26]; this process is high in cysteine [27]. Engler et al. [28] reported that less cysteine is required by male broiler genotypes that are low feathering $\left(\mathrm{L} / \mathrm{k}^{+}\right)$after the age of 3 weeks, and this results in a 15\% advantage in the feather weight of the $\mathrm{k}^{+} / \mathrm{k}^{+}$bird at the age of 48 days [29]. If the nutrients are stored in the feathers then it will not be available for other purposes; while the muscle of breast nourishment rate is reduced by the continuous production of keratin, which limits the supply of nutrients [30]. Therefore, the cystine deficiency results in the reduction in the recovery of breast meat and also decreases the extent of feathering. Our finding of no effects of the sources of methionine on the starter phase of broilers is supported by other researchers [22,31] who observed that L-Met and DL-Met did not affect growth performance due to conversion of DL-Met into L-Met. It seems that lower metabolization of D-amino acid due to the lower amount of D-amino acid oxidase in young broilers may reduce the utilization of higher amounts of DL-Met, which leads to metabolic stress and inhibition of body weight gain in the starter phase. Our findings regarding unaltered feed intake, weight gain and FCR of broilers in the starter period due to different levels of methionine are similar to those of other researchers [32,33], which might be attributed to the satisfaction of methionine requirements at the lower standard level.

The results regarding feed intake of broilers in the finisher period indicated significant differences $(p<0.05)$ between L-Met and DL-Met. This finding confirmed the reports of earlier researchers [34] who observed better feed efficiency of chicks fed an L-Met diet as compared to DL-Met because the supplementation of either L-Met or DL-Met have beneficial effects on villus development in association with increased glutathione production and levels of total antioxidant capacity, and reduced protein oxidation in the duodenum. Supplementation of L-Met has a better effect on redox status and development of the gut of young chicks as compared with DL-Met. 
Our finding of no changes in the weight gain of broilers in the finisher period by the combined effect of L-Met and DL-Met is the similar to other researchers $[33,35,36]$ who observed that L-Met or DL-Met did not significantly influence the weight gain of broilers in the finisher period. This was because when large quantities of methionine are added in the feed, excess methionine is converted into homocysteine and higher amounts of homocysteine in the body reduce the body weight of broilers [37]. No significant differences $(p>0.05)$ were observed by different type of methionine on feed intake, weight gain, and FCR of broilers in the finisher period. This finding confirms the reports of earlier researchers $[32,33,38]$. Because d-amino acid oxidase, the key enzyme that converts D-Met to L-Met, exists only in the liver and kidney, D-Met is not utilized directly by the cells of the gastrointestinal tract until it is converted to L-Met either in the liver or kidneys. Research has also shown that the expression of this enzyme is very low for young animals. Therefore, L-Met is the only biologically functional form of methionine that is readily utilized by the intestinal cells of young animals. The quantity of methionine had no effect $(p>0.05)$ on the performance of broilers in the finisher period. This finding confirms the reports of earlier researchers [21,22] who observed that levels of methionine had no effect on feed intake, average daily gain, feed efficiency and FCR of broilers because DL-Met is readily converted into the L-isomer by the animal. Also, our finding that L-Met and DL-Met had no combined effect on feed intake, weight gain and FCR during the overall phase of broiler growth is supported by other researchers $[33,35,36]$ who also observed that L-Met or DL-Met did not influence the feed intake, weight gain and overall FCR of broilers. Zhang [7] studied the effect of different dietary methionine source supplementation including L-Met, DL-Met and DL-2-hydroxy-4-(methylthio) butanoic acid (DL-HMTBA) on growth performance. He observed no differences among L-Met, DL-Met and DL-HMTBA for weight gain and feed efficiency. No effect of methionine sources on overall growth of broiler has also been found by other researchers [21,22,31] who observed that L-Met and DL-Met had no effect on the overall phase of broilers.

The results regarding thigh weight indicated that the highest value $(p<0.05)$ was achieved at the $80 \%$ ratio of L-Met, while the values achieved at the $80 \%$ ratio of DL-Met were lower than L-Met. The significant effect of L-Met and DL-Met on the thigh weight of broilers is supported by other researchers $[39,40]$ who also observed that methionine sources improved the thigh weight of broilers because methionine has a role in the synthesis of creatinine in thigh muscles. No differences $(p>0.05)$ were observed for different types of amino acid on the carcass characteristics of broilers. This finding confirmed the reports of earlier researchers [31,41] who observed that the type of methionine had no effect on live weight, carcass weight, after skin removal, eviscerated weight and chest weight because L-Met is directly absorbed in the body and DL-Met, MHA is first converted into L-Met and then absorbed in the body. Also, Drazbo et al. [42] found that the source of dietary methionine had no effect on carcass yield or breast muscle quality.

The levels of methionine had a significant $(p<0.05)$ effect on carcass weight, chest weight and thigh weight. This finding confirms previous studies [43,44], where levels of methionine had a significant influence on the thigh weight, chest weight and carcass weight. This is because D-Met is oxidatively converted to $\alpha$-ketoanalogues of L-Met, 2-keto-4(methylthio) butanoic acid (KMB) by the enzyme D-amino acid oxidase, which is a proximal oxidase containing flavin adenine dinucleotide (FAD) as a cofactor. Then, KMB is converted into L-methionine by the transfer of nitrogen from the donor amino acid, which is catalyzed by ubiquitous transaminases. In chickens, many amino acids like glutamic acid, arginine, isoleucine and alanine are used for transamination of KMB [7,11].

Results regarding liver weight indicated that the highest value $(p<0.05)$ was observed at the $80 \%$ ratio of L-Met while the values achieved at the $80 \%$ ratio of DL-Met were lower than L-Met. The combined effect of L-Met and DL-Met had a significant $(p<0.05)$ effect on the liver weight of broilers. Our finding of unaltered heart and gizzard weight due to the combined effect of L-Met and DL-Met is supported by other researchers $[45,46]$ who observed that DL-Met and herbal methionine had no significant effect on the carcass yield, breast meat and eviscerated weight of broilers. The significant differences observed between the heart and liver weight of birds fed different types of 
amino acid are corroborated by Ahmed and Abbas [45] who observed that dietary supplementation of methionine significantly affected the liver and heart weight. Ribeiro et al. [35] observed that DL-Met had a significant effect on the gizzard weight in heat stress conditions, which is similar to our findings of differences in gizzard weight due to the type of amino acid.

Unaltered homocysteine due to the combined effect of L-Met and DL-Met in the diet of broilers was supported by the findings of Pillai et al. [47]. They observed that dietary methionine had no effect on hepatic homocysteine remethylation. No effect of the source of methionine on serum homocysteine level of broilers confirms the findings of Harter and Baker [48] who observed that methionine was stored in the plasma of birds fed excess methionine, but plasma levels of homocysteine, cystathionine, and cystine remained unchanged. Haulrik et al. [49] found that high methionine and high protein diet did not significantly increase homocysteine concentration as compared to low methionine and low protein diet, which confirms our findings that there was no change in serum homocysteine level due to different amino acid sources.

On the basis of these results, it may be concluded that if DL-Met and L-Met are included at a standard level in feed, they are equally effective as a source of methionine for broilers. However, better carcass traits may be achieved if Met + Cyst is added at the rate of $80 \%$ of digestible lysine.

Author Contributions: Data curation, A.U.R. and M.E.A.E.-H.; Formal analysis, M.A.A.-L.; Investigation, M.A. (Muhammad Arif); Methodology, M.M.H.; Resources, S.I.O.; Software, A.E.T.; Visualization, M.A. (Mahmoud Alagawany) and A.A.A.; Writing-review \& editing, M.E.A.E.-H. and S.S.E.

Acknowledgments: This research was funded by the Deanship of Scientific Research at Princess Nourah bint Abdulrahman University through the Fast-Track Research Funding Program.

Conflicts of Interest: The authors declare no conflict of interest.

\section{References}

1. Alagawany, M.; Abd El-Hack, M.E.; Arif, M.; Ashour, E.A. Individual and combined effects of crude protein, methionine, and probiotic levels on laying hen productive performance and nitrogen pollution in the manure. Environ. Sci. Pollut. Res. 2016, 23, 22906-22913. [CrossRef] [PubMed]

2. Bunchasak, C. Role of dietary methionine in poultry production. J. Poult. Sci. Assoc. 2009, 46, 169-179. [CrossRef]

3. Elnesr, S.S.; Elwan, H.A.M.; Xu, Q.Q.; Xie, C.; Dong, X.Y.; Zou, X.T. Effects of in ovo injection of sulfur-containing amino acids on heat shock protein 70, corticosterone hormone, antioxidant indices, and lipid profile of newly hatched broiler chicks exposed to heat stress during incubation. Poult. Sci. 2019, 98, 2290-2298. [CrossRef] [PubMed]

4. Elwan, H.A.; Elnesr, S.S.; Xu, Q.; Xie, C.; Dong, X.; Zou, X. Effects of in ovo methionine-cysteine injection on embryonic development, antioxidant status, IGF-I and tlr4 gene expression, and jejunum histomorphometry in newly hatched broiler chicks exposed to heat stress during incubation. Animals 2019, 9, 25. [CrossRef]

5. Binder, M. Life cycle analysis of DL-methionine in broiler meat production. In Information for the Feed Industry; Degussa feed additives: Hanau-Wolfgang, Germany, 2003; pp. 1-8.

6. Schutte, J.B.; de Jong, J.; Smink, W.; Pack, M. Replacement value of betaine for DL methionine in male broiler chicks. Poult. Sci. 1997, 76, 321-325. [CrossRef]

7. Zhang, S. Physiological and Biochemical Aspects of Methionine Isomers and Precursor in Broilers. 2016, pp. 10919-11120. Available online: https://vtechworks.lib.vt.edu (accessed on 3 June 2016).

8. Riberio, A.L.M.; Dahlke, F.; Kessler, A.M. Methionine sources do not affect the performance and carcass yield of broiler fed vegetable diet and submitted to cylic heat stress. Braz. J. Poult. Sci. 2005, 3, 159-164. [CrossRef]

9. Fang, Z.; Yao, K.; Zhang, X.; Zhao, S.; Sun, Z.; Tian, G.; Zhang, K. Nutrition and health relevant regulation of intestinal sulfur amino acid metabolism. Amino Acids 2010, 39, 633-640. [CrossRef]

10. Baker, D.H.; Boebel, K.P. Utilization of D- and L-Isomer of methionine and methionine hydroxy analogue as determined by chicken. Bioassay J. Nutr. 1980, 110, 959-964.

11. Meirelles, H.T.; Albuquerque, R.; Borgatti, L.M.O.; Souza, L.W.O.; Meister, N.C.; Lima, F.R. Performance of Broilers Fed with Different Levels of Methionine Hydroxy Analogue and DL-Methionine. Braz. J. Poult. Sci. 2003, 1, 69-74. [CrossRef] 
12. Jankowski, J.; Kubińska, M.; Zduńczyk, Z. Nutritional and immunomodulatory function of methionine in poultry diets-A review. Am. J. Anim. Sci. 2014, 14, 17-31. [CrossRef]

13. Kalinowski, A.; Moranjr, E.T.; Wytta, C.L. Methionine and Cystine requirement of slow and fast feathering broiler males from three to six week. Poult. Sci. 2003, 82, 1428-1437. [CrossRef] [PubMed]

14. Xie, M.; Hou, S.S.; Huang, W.; Zhao, L.; Yu, J.Y.; Li, W.Y.; Wn, Y.Y. Interrelationship between Methionine and Cystine of Early Peking Duckling. Poult. Sci. 2004, 83, 1703-1708. [CrossRef] [PubMed]

15. Lui, Z.; Bateman, A.; Bryant, M.M.; Zinner, B.; Roland, A.D. Performance comparisons between DL-methionine and DL-methionine hydroxy analogue in layers on an unequal molar basis. J. Appl. Poult. Res. 2005, 14, 569-575.

16. Goulart, C.C.; Costa, F.G.P.; Silva, J.M.V.; Souza, J.G.; Rodrigues, V.P.; Santos, C.F. Requirements of digestible methionine + Cystine for broiler chicken at 1 to 42 day of age. Revista Brasileira de Zootecnia 2011, 40, 797-803. [CrossRef]

17. Ubbink, J.B.; Vermaak, W.J.H.; Bissbort, S. Rapid high-performance liquid chromatographic assay for total homocysteine level in human serum. J. Chromatogr. 1991, 565, 441-446. [CrossRef]

18. Ahmed, M.E.; Abbas, T.E. Effects of dietary levels of methionine on broiler performance and carcass characteristics. Int. J. Poult. Sci. 2011, 10, 147-151.

19. National Research Council. Nutrient Requirements of Poultry, 9th ed.; National Academy Press: Washington, DC, USA, 1994.

20. Katz, R.S.; Baker, D.H. Efficacy of D-, L-, and DL-Methionine for growth of chicks fed crystalline amino acid diet. Poult. Sci. 1975, 54, 1667-1674. [CrossRef]

21. Dilger, R.N.; Baker, D.H. DL-Methionine is an efficacious as L-Methionine but modest L-Cystine excesses are anorexigenic in sulfur amino acid deficient purified and practical type diet fed to chick. Poult. Sci. 2007, 86, 2367-2374. [CrossRef]

22. Powell, C.D.; Kabir Choudry, M.A.; Bureau, D.P. Accessing the bioavailability of L-Methionine and methionine hydroxy analog (MHA-Ca) Compared to DL-Methionine in rainbow trout. Agric. Res. 2015, 1-15. [CrossRef]

23. Creek, R.D. Nonequivalence in mass in the conversion of phenylalanine to tyrosine and methionine to cystine. Poult. Sci. 1968, 47, 1385-1386. [CrossRef]

24. Baker, D.H.; Fernandez, S.R.; Webel, D.M.; Parsons, C.M. Sulfur amino acid requirement and cystine replacement value for broiler chicken during the period 3 to 6 week post hatching. Poult. Sci. 1996, 75, 737-742. [CrossRef] [PubMed]

25. Wheeler, K.B.; Latshaw, J.D. Sulfur amino acid requirements and interactions in broilers during two growth periods. Poult. Sci. 1981, 60, 228-236. [CrossRef] [PubMed]

26. Hancock, C.E.; Bradford, G.D.; Emmans, G.C.; Gous, R.M. The evaluation of the growth parameters of six strains of commercial broiler chickens. Braz. J. Poult. Sci. 1995, 36, 247-264. [CrossRef] [PubMed]

27. Stilborn, H.L.; Moran, E.T.; Gous, R.M.; Harrison, M.D. Effect of age on feather amino acid content in broiler strain crosses and sexes. J. Appl. Poult. Res. 1997, 6, 205-209. [CrossRef]

28. Engler, K.; Thomas, O.P.; Bossard, E. The sulfur amino acid requirement of 3-week old broilers. In Proceedings of the Maryland Nutrition Conference for Feed Manufacturers, College Park, MD, USA, 21-22 March 1985; University of Maryland: College Park, MD, USA, 1985; pp. 5-10.

29. Ajang, O.A.; Prijono, S.; Smith, W.K. Effect of dietary protein content on growth and body composition of fast and slow feathering broiler chickens. Braz. Poult. Sci. 1993, 34, 73-91. [CrossRef]

30. Wylie, L.M.; Robertson, G.W.; Macleod, M.G.; Hocking, P.M. Effect of ambient temperature and restricted feeding on the growth of feathers in growing turkeys. Braz. J. Poult. Sci. 2001, 42, 449-455. [CrossRef]

31. Ullrich, C.; Langeheine, M.; Brehm, R.; Taube, V.; Galera, M.R.; Rohn, K.; Popp, J.; Visscher, C. Influence of Different Methionine Sources on Performance and Slaughter Characteristics of Broilers. Animals 2019, $9,984$. [CrossRef]

32. Khajali, F.; Moghaddam, H.N. Methionine supplementation of low protein broiler diets influence of growth performance and efficiency of protein utilization. Int. J. Poult. Sci. 2006, 5, 569-573.

33. Kluge, H.; Gessner, D.K.; Herzog, E.; Eder, K. Efficacy of DL methionine hydroxy analogue free acid in comparison to DL methionine in growing male white pekin ducks. Poult. Sci. 2015, 95, 590-594. [CrossRef]

34. Shen, Y.B.; Ferket, P.; Park, I.; Malheiros, R.D.; Kim, S.W. Effect of feed graded L-methionine on intestinal redox status, intestinal development, and growth performance of young chickens compared with conventional DL-methionine. J. Anim. Sci. 2015, 93, 2977-2986. [CrossRef] 
35. Ribeiro, A.L.M.; Penz, J.R.A.M.; Teeter, R.G. Effect of 2 hydroxy 4 methylthio butanoic acid and DL-Methionine on broiler performance and compensatory growth after exposure of two different environmental temperature. J. Appl. Poult. Res. 2001, 10, 419-426. [CrossRef]

36. Panda, A.K.; Rama Rao, S.V.; Raju, M.V.L.N.; Bhanja, S.K. Relative performance and immune response in white leghorn layers fed liquid DL-methionine hydroxy analog and DL-methionine. Asian Australas. J. Anim. Sci. 2007, 20, 948-953. [CrossRef]

37. Hayat, Z.; Rehman, A.; Akram, K.; Farooq, U.; Saleem, G. Evaluation of a natural methionine source on broiler growth performance. J. Sci. Food Agric. 2015, 95, 2462-2466. [CrossRef] [PubMed]

38. Lui, Y.L.; Song, G.L.; Yi, G.F.; Hou, Y.Q.; Huang, J.W.; Knight, C.D. Effect of supplementing 2 hydroxy 4 methylthio butanoic acid (HMTBA) and DL-Methionine in corn soybean-cotton seed meal diet on growth performance and carcass quality of broilers. Asian Australas. J. Anim. Sci. 2006, 19, 1197-1205.

39. Hesabi, A.; Nasiri, H.; Birjandi, M. Effect of supplemental methionine and Lysine on performance and carcass yield characteristics in broiler chicken. World Poult. Sci. Assoc. 2006, 16, 112-117.

40. Lemme, A.; Hoehler, D.; Brennan, J.J.; Mannion, P.F. Relative effectiveness of methionine hydroxy analog compared to DL-methionine in broiler chickens. Poult. Sci. 2002, 81, 838-845. [CrossRef]

41. Murawska, D.; Kubinska, M.; Gesek, M.; Zdunczyk, Z.; Brzostowska, U.; Jankowski, J. The effect of different dietary levels and sources of methionine on growth performance of turkey, Carcass and meat Quality. Ann. Anim. Sci. 2018, 2, 525-540. [CrossRef]

42. Drazbo, A.; Kozlowski, K.; Siwiecka, L.C.; Sobczak, A.; Kwiatkowski, P.; Lemme, A. Effect of different dietary level of DL-methionine and calcium salt of DL-2-hydroxy-4-(methyl) butanoic acid on the growth performance, carcass yield and meat quality of broiler chickens. Eur. Poult. Sci. 2015, 79, 1-15.

43. Nukreaw, R.; Bunchasak, C.; Markvichtir, K.; Choothesa, A.; Prasanpanich, S.; Loongyai, W. Effects of methionine supplementation in low-protein diets and subsequent re-feeding on growth performance, liver and serum lipid profile, body composition and carcass quality of broiler chickens at 42 days of age. J. Poult. Sci. 2011, 48, 229-238. [CrossRef]

44. Yoo, J.; Yi, Y.J.; Wickramasuriya, S.S.; Kim, E.; Shin, T.K.; Cho, M.H.; Kim, N.; Heo, J.M. Evaluation of sulphur amino acid requirement of male Korean native duckling from hatch to 21 day of age. Br. Poult. Sci. 2017, 58, 272-277. [CrossRef]

45. Ahmed, M.E.; Abbas, T.E. The effect of feeding herbal methionine versus dl-methionine supplemented diets on broiler performance and carcass characteristics. In Proceedings of the International Conference on Agricultural, Ecological and Medical Sciences (AEMS-2015), Penang, Malaysia, 10-11 February 2015.

46. Kaur, D.; Nagra, S.S.; Sodhi, S.; Dwivedi, P. Comparative performance of commercial broiler fed Herbomethionine as a replacement for DL-Methionine in diet. J. Appl. Anim. Res. 2013, 4, 410-416. [CrossRef]

47. Pillai, P.B.; Fanatico, A.C.; Beers, K.W.; Blair, M.E.; Emmert, J.L. Homocysteine remethylation in young broiler fed varying levels of Methionine, Choline and Betaine. Poult. Sci. 2006, 85, 90-95. [CrossRef] [PubMed]

48. Harter, J.M.; Baker, D.H. Factors affecting methionine toxicity and its alleviation in the chick. J. Nutr. 1978, 108, 1061-1070. [CrossRef] [PubMed]

49. Haulrik, N.; Toubro, S.; Dyerberg, J.; Stender, S.; Skov, A.R.; Astrup, A. Effect of protein and methionine intakes on plasma homocysteine concentrations: A 6-mo randomized controlled trial in overweight subjects. Am. J. Clin. Nutr. 2002, 76, 1202-1206. [CrossRef] [PubMed]

C 2019 by the authors. Licensee MDPI, Basel, Switzerland. This article is an open access article distributed under the terms and conditions of the Creative Commons Attribution (CC BY) license (http://creativecommons.org/licenses/by/4.0/). 